\title{
THE EFFECT OF LIQUID ORGANIC FERTILIZER OF ROBUSTA COFFEE ON THE PRODUCTIVITY OF RED CRY CHILI (Capsicum annuum L.)
}

\author{
Yuli Cahyaningsih ${ }^{1 *}$, Ervina Titi Jayanti ${ }^{1}$, M.Harja Efendi ${ }^{1}$ \\ ${ }^{1}$ Biology Education Department - State Islamic University of Mataram \\ *Corresponding author, email :yulicahyaningsih81@gmail.com
}

\section{ARTICLE INFO \\ Article history \\ Received $03^{\text {th }}$ of Sept., 2020 \\ Revised $10^{\text {th }}$ of Okt., 2020 \\ Accepted $12^{\text {th }}$ of Okt., 2020 \\ Published $12^{\text {th }}$ of Nov., 2020}

\section{Keywords}

Liquid organic fertilizer

Coffee skin waste

Red chili plant growth

\section{ABSTRACT}

This study aims to determine the effect of liquid organic fertilizer from Robust coffee peels on the productivity of curly red chilies (Capsicum annum L). This type of research is quantitative, the research approach used is experimental by using a completely randomized design RAL consisting of 7 treatments of 5 replications so that there are 35 experimental units and are placed randomly, namely $0 \%$ fertilizer (P0), $10 \%$ fertilizer (P1), fertilizer. $20 \%(\mathrm{P} 2)$, $30 \%$ fertilizer (P3), 40\% fertilizer (P4), 50\% fertilizer (P5), 60\% fertilizer (P6). The data analysis technique used One-way ANOVA with a significance level of 5\% and the LSD advanced test. ANOVA test results show that the comparison of the effect of liquid organic fertilizer on robust coffee peels has an effect on vegetative growth and generative growth in curly red chilies (Capasicum annum L.). Fertilizer treatment with a concentration of $50 \%$ (P5) had the most significant effect on the number of flowers, number of fruits, wet weight and dry weight of curly red chilies. On the growth of the number of leaves, the concentration of $30 \%$ (P3) also gave the highest effect and yield although not significant. The 50\% concentration (P5) was the optimal concentration for the growth of plant height and length of curly red chili plants.

Copyright $($ 2020, Cahyaningsih et al. This is an open access article under the CC-BY-SA license

\section{A. INTRODUCTION}

Organic agriculture has long been known by humans, since the science of farming was applied by our ancestors. At that time everything was done in the traditional way and using natural ingredients. Indonesia has a very large base capital to develop organic agriculture (Ida Syamsu Roidah, 2013). Organic fertilizers are natural fertilizers that can be obtained directly from nature, for example natural phosphate, manure, green manure, and compost (Baon et al., 2005). Coffee is a source of foreign exchange for Indonesia and plays an important role in the development of the plantation industry. In 1980, the area and production of smallholder coffee plantations amounted to 663 thousand hectares and 276 thousand tons, respectively. Coffee husk waste contains organic materials and nutrients that have the potential to be used as a planting medium. The results showed the level of C. 
Organic coffee skin was $45.3 \%$ nitrogen content $2.98 \%$ phosphorus $0.18 \%$ and potassium $2.26 \%$. According to research by Yanuarti \& Afsari (2016) the addition of organic fertilizer from coffee husk waste to plant media has a significant effect on the growth of coffee seeds, namely in high growth.

Chili plants are vegetables that have a high economy, chilies contain many kinds of compounds that are useful for human health, chili contains antioxidants that function to protect the body from free radical attacks. According to data from the Central Statistics Agency of the Republic of Indonesia (2018) Indonesian chili production reached 12 million tonnes, for the productivity of red chilies in West Nusa Tenggara alone in 2018 reached 23,997 tonnes, while the level of consumption of red chilies in particular reached 2,988 tonnes. It can be seen from the data that has been explained that chili production from year to year fell drastically due to elemental requirements. The growth of chilies is very minimal, so to continue to increase the productivity of curly red chilies (Capsicum annum L.), the author provides a new breakthrough by utilizing liquid organic fertilizer from coffee peels as an alternative to increasing the productivity of curly red chilies (Capsicum annum L.) (BPS, 2019).

The purpose of this study was to determine the effect of liquid organic fertilizer on robusta coffee peels on the productivity of curly red chilies (Capsicum annum L.).

\section{B. METHOD}

The research was conducted from March to July 2020. The place of this research was carried out in Lamoke Village, Gerung District, West Lombok Regency. This type of research is an experimental research that tests several concentrations of liquid organic fertilizer from coffee peels on the productivity of red chili plants (Capsicum annum L.). The research variable in this study was the independent variable, namely the concentration of liquid organic fertilizer from coffee peels. The dependent variable in this study was the productivity of the curly red chili (Capsicum annum L.) which included parameters, namely number of leaves, number of fruit, time of appearance of flowers, number of flowers, height. curly red chili plants, stem length, stem diameter, wet weight and dry weight.

The design used in this study was a completely randomized design (CRD) with one factor, namely the application of variations in the concentration of coffee peel liquid organic fertilizer consisting of 4 levels of concentration $\mathrm{P} 0=$ Control (without giving organic coffee husk organic fertilizer. P1 = Provision of liquid organic fertilizer from coffee peels. concentration of $10 \%$. P2 = Provision of liquid organic fertilizer with a concentration of $20 \%$. P3 = Provision of liquid organic fertilizer with a concentration of $30 \%$. P4 = Provision of liquid organic fertilizer with a concentration of $40 \%$. P5 = Provision of liquid organic fertilizer with a concentration of $50 \%$. P6 = Provision of organic liquid coffee husk fertilizer with a concentration of $60 \%$ with 7 treatments and 5 replications. The research instrument was carried out on a privately owned experimental land in the village of Lamokek Gerung, West Lombok. The research was started from March to July 2020. The materials used in the study are the seeds of curly red chili (Capsicum annum L.) varieties of F1 and Laba varieties, liquid organic fertilizer from Robusta Coffee peels, sugar, and water. The tools used in this study were hoes, buckets, 
small sticks, scoops, measuring cups, scales, rulers, gauges, sample scrapers, stationery and other tools that support the implementation. Data analysis in this study was to determine the effect of variations in fertilizer concentration. Liquid organic coffee peels on plant productivity of curly red chilies (Capsicum annum L.) The data obtained are raw data from observations consisting of plant height, stem diameter, number of leaves, number of flowers, number of fruits, dry weight, and wet weight along with the time of appearance flower. The data were analyzed using the annova test which aims to determine the normality and homogeneity tests.

\section{RESULTS AND DISCUSSION}

1. Negative growth

The results of the analysis of the average vegetative growth on the productivity of curly red chili plants (Capsicum annum L.) were observed Table 3.1.

Table 3.1. Vegetative growth average

\begin{tabular}{ccrrrr}
\hline \multirow{2}{*}{ Number } & \multicolumn{5}{c}{ Parameter $(\mathrm{cm})$} \\
\cline { 2 - 6 } & Treatment & Stem length & Stem diameter & Stem height & Number of leaves \\
\hline 1 & P0 & 26.5 & 0.9 & 37.3 & 74.8 \\
2 & P1 & 27.2 & 1.0 & 38.5 & 79.1 \\
3 & P2 & 27.8 & 1.0 & 39.4 & 60.8 \\
4 & P3 & 30.2 & 1.1 & 41.3 & 101.5 \\
5 & P4 & 29.6 & 1.2 & 41.6 & 68.1 \\
6 & P5 & 30.5 & 1.2 & 43.2 & 99.1 \\
7 & P6 & 31.4 & 1.4 & 54.2 & 84.3 \\
\hline
\end{tabular}

2. Generative Growth

The results of the analysis of the average generative growth on the productivity of curly red chilies (Capsicum annum L.) were observed in Table 3.2.

Table 3.2. Generative growth average

\begin{tabular}{ccrrrr}
\hline \multirow{2}{*}{ Number } & \multicolumn{5}{c}{ Parameter (gram) } \\
\cline { 2 - 6 } & Treatment & Total interest & Number if fruits & Fritu weight & Weight of fruit dry \\
\hline 1 & P0 & 6.3 & 4.8 & 52.8 & 24.4 \\
2 & P1 & 8.5 & 4.7 & 50.2 & 22.6 \\
3 & P2 & 6.6 & 6.8 & 85.4 & 35.6 \\
4 & P3 & 6.9 & 8.1 & 103.8 & 43.6 \\
5 & P4 & 6.9 & 7.3 & 92.6 & 38.8 \\
6 & P5 & 10.2 & 9.4 & 139.4 & 57.6 \\
7 & P6 & 9.0 & 5.7 & 62.0 & 28.6 \\
\hline
\end{tabular}

Table 3.3. LSD test data for the number of curly red chilies

\begin{tabular}{ccc}
\hline Treatment & Repeat & Average \\
\hline P0 & 5 & $12,8^{\mathrm{a}}$ \\
P1 & 5 & $12^{\mathrm{a}}$ \\
P2 & 5 & $19,2^{\mathrm{b}}$ \\
P3 & 5 & $23,,^{\mathrm{c}}$ \\
P4 & 5 & $20^{\mathrm{bc}}$ \\
P5 & 5 & $30,2^{\mathrm{d}}$ \\
P6 & 5 & $14,4^{\mathrm{a}}$ \\
\hline
\end{tabular}

The results of data analysis obtained from ANOVA for the number of fruit of curly red chilies are F count 31,776 while $\mathrm{F}$ table at the 5\% level is 2.87 and the level $1 \%$ is 5.95 . 
The data shows that $\mathrm{F}$ count $>\mathrm{F}$ table, which means liquid organic fertilizer (POC) of coffee peels as fertilizer has a significant effect on the number of curly red chilies (Capsicum annum L.) (Table 3.3).

The results of data analysis were obtained from the LSD further test for the total dry weight of the curly mera (Capsicum annum L.) plant, namely the average treatment $\mathrm{P} 0$ was significantly different from treatment P2, P3, P4 and P5 because it had a notation b while the average value of treatment P0 is significantly different from treatment P1 and P6 because they both have a notation.

The results of data analysis obtained from ANOVA for the amount of wet weight of the fruit of the curly red chili is F count 33.818 while $\mathrm{F}$ table at the 5\% level is 2.87 and the level of $1 \%$ is 5.95 . The data shows that $\mathrm{F}$ count $>\mathrm{F}$ table means that liquid organic fertilizer (POC) of coffee peels as fertilizer has a significant effect on the wet weight of curly red chilies (Capsicum annum L.), then the LSD test is continued to determine whether there is a difference between the average average for each treatment. The results of the LSD further test for the amount of wet weight are as shown in the following Table 3.4 .

Table 3.4. LSD test data Wet weight of curly red chilies

\begin{tabular}{ccc}
\hline Treatment & Repeat & Average \\
\hline P0 & 5 & $52,8^{\mathrm{a}}$ \\
P1 & 5 & $50,2^{\mathrm{a}}$ \\
P2 & 5 & $85,4^{\mathrm{b}}$ \\
P3 & 5 & $103,8^{\mathrm{b}}$ \\
P4 & 5 & $92,6^{\mathrm{b}}$ \\
P5 & 5 & $139,4^{\mathrm{c}}$ \\
P6 & 5 & $62^{\mathrm{a}}$ \\
\hline
\end{tabular}

The results of data analysis obtained from the LSD further test for the amount of wet weight of curly red chili (Capsicum annum L.), namely the average treatment P0 was not significantly different from treatment P1 and P6 because it had the same notation, the average value of treatment P0 was not different. Significant with treatment P2, P3, and P4 because it has a notation $b$ and the mean value of treatment P0 is significantly different from treatment P5 because it has a notation c. Based on the growth parameters that have been determined by the researcher, namely plant height, number of leaves, number of flowers, stem diameter, stem length, dry weight, time of appearance of flowers, wet weight and number of fruit on curly red chili (Capsicum annum L.) ANOVA showed that the ratio of variations in the concentration of liquid organic fertilizer from coffee peels had an effect on the productivity of curly red chilies (Capsicum annum L.), $50 \%$ fertilizer concentration, the fifth treatment had the most significant effect on the number of fruits with an average of 139.4 gr, wet weight of fruit 94 and dry weight of fruit 57.6 gr, number of flowers 10.2 g. On the growth of leaves, the concentration of $30 \%$ also gave the highest effect, although not significant. The $50 \%$ concentration of the fifth treatment was the optimal concentration for the productivity of curly red chilies (Capsicum annum L.).

In this case the temperature factor also greatly affects the growth of chilies, the temperature conditions at the place where chili is planted is an average of $28 \mathrm{C}^{\wedge} 0$, 
temperature affects plant growth and development on metabolic rate, photosynthesis. Growth and yield of chili plants is also influenced by weather factors.

The availability of nutrients absorbed by the plant can be fulfilled from the fermentation process of the coffee husk raw material so that the optimal concentration of liquid organic fertilizer from the coffee husks on curly red chili plants is 50\%. According to Dzung et al., (2013), the skin of the coffee fruit contains nitrogen (N) of $1.27 \%$, phosphorus (P) $0.06 \%$, and potassium (K) $2.46 \%$ (Qibtiah \& Astuti, 2016).

Coffee husk waste which contains organic materials that can be used as liquid organic fertilizer can be applied to any plant including the research plan to be applied to curly red chili plants (Capsicum annum L.) with a high increase in the number of leaves due to high absorption of nitrogen. The most important vital nutrients in plants, nitrogen compounds are converted into amino acid compounds, nitrogen compounds $(\mathrm{N})$ form important compounds such as chlorophyll, nucleic acids and enzymes, at concentrations of P3 the average number of leaves reaches 101, mst, this is because plants are quite good at absorption element nitrogen.

\section{CONCLUSION}

From the research results, it can be concluded that the coffee coolie liquid organic fertilizer has an effect on the nine growth parameters, namely the number of leaves, the number of flowers, the height of the stem, the length of the plant, the diameter of the stems, the time when the flowers appear has an effect but is not significant, the plants that get enough nitrogen can stimulate vegetative growth. While the dry wet weight of the fruit, the dry weight of the fruit and the number of fruits have a significant effect. This is because the element phosphorus plays a role in stimulating root growth, flowers and fruit ripening and plays an important role as a constituent of plant fat and plant protein nuclei and the data shows the average concentration. $50 \%$ has a very significant effect on the growth of curly red chilies (Capsicum annum L.). The successful use of coffee husks as liquid organic fertilizer provides multiple benefits, in addition to restoring soil fertility, it can also reduce environmental pollution with coffee waste.

\section{E. REFERENCES}

Ida Syamsu Roidah. (2013). Manfaat Penggunaan Pupuk Organik Untuk Kesuburan Tanah. Jurnal Universitas Tulungagung BONOROWO, 1(1), 30-42.

Qibtiah, M., \& Astuti, P. (2016). Pertumbuhan Dan Hasil Tanaman Bawang Daun (Allium fistulosum L.) Pada Pemotongan Bibit Anakan Dan Pemberian Pupuk Kandang Sapi Dengan Sistem Vertikultur. Jurnal AGRIFOR, XV(June 2014), 249-258.

Yanuarti, A. R., \& Afsari, M. D. (2016). Profil Komoditas Barang Kebutuhan Pokok dan Barang Penting Komoditas cabai. Badan Kementerian Perdagangan, 59.

Baon, J.K.R, Sukasih, Nurkholis. 2005. Laju Dekomposisi dan Kualitas Kompos Limbah Padat Kopi: Pengaruh Aktivator dan Bahan Baku Kompos. Pelita Perkebunan 21(1).

Badan Pusat Statistik (BPS). 2019. Distribusi Perdagangan Komoditas Cabai Merah Indonesia. BPS Republik Indonesia. 